\title{
DIALEKTIKA RITUAL DAN HIBURAN DALAM KESENIAN BARONGAN DI KABUPATEN BLORA JAWA TENGAH
}

\author{
Endik Guntaris ${ }^{1}$ \\ Program Studi Pendidikan Seni, Universitas Negeri Semarang \\ 1endikguntaris@ymail.com
}

\begin{abstract}
ABSTRAK
Penelitian ini bertujuan mengkaji kesenian Barongan (local wisdom) yang tengah mengalami masalah perbedaan kepentingan, yakni kepentingan ritual dan kepentingan hiburan. Barongan merupakan refleksi kreatifitas seni dan budaya masyarakat Blora yang memiliki sifat kerakyatan dan syarat makna. Di antara maknanya adalah kekuatan dahsyat yang disimbolkan dengan bentuk Singa dari topeng Barongan.

Lokasi penelitian di empat desa kabupaten Blora Jawa Tengah Indonesia. Penelitian kualitatif ini menggunakan pendekatan performance studies dengan sub pendekatan etnokoreologi. Pengumpulan data dilakukan dengan teknik observasi, wawancara mendalam, studi dokumen, dan analisis isi.

Hasil penelitian menunjukkan bahwa ada dialektika antara kepentingan ritual dan hiburan dalam pertunjukan Barongan. Kedua kepentingan tersebut saling bersaing, saling bersanding, dan saling mempengaruhi dalam hal penyajian maupun strategi menarik animo penontonnya. Selain itu, ada dua bentuk (model) penyajian Barongan yang berhubungan dengan fungsinya, yaitu bentuk arak-arakan dan dramatari.
\end{abstract}

Kata kunci: kesenian Barongan, ritual, dan hiburan.

\section{PENDAHULUAN}

Kesenian Barongan atau seni pertunjukan Barong banyak terdapat di daerah Jawa Tengah, seperti kabupaten Blora, Rembang, Pati, dan Tegal, bahkan dapat dikatakan bahwa Barongan merupakan salah satu kesenian khas Jawa Tengah. Keberadaan Barongan di Blora secara kuantitas lebih banyak dibandingkan dengan daerah lain yang ada di Jawa Tengah. Oleh karena itu, kesenian Barongan merupakan kesenian rakyat yang amat populer di Blora. Di dalam Barongan tercermin sifat-sifat kerakyatan dan keakraban masyarakat Blora, yakni spontanitas, kekeluargaan, kesederhanaan, kasar, keras, kompak, dan keberanian yang dilandasi kebenaran.

Kata "barongan" menunjuk pada suatu pelengkapan (topeng beserta asesorisnya) yang dibuat menyerupai Singa Barong (Singa besar dan sangat buas) sebagai penguasa hutan angker. Kesenian Barongan berbentuk tarian kelompok yang 
menirukan keperkasaan gerak seekor singa raksasa. Singo Barong atau disebut Gembong Amijoyo adalah tokoh utama dan dominan kesenian Barongan. Cerita dalam kesenian Barongan bersumber dari hikayat Panji, yaitu suatu cerita perjalanan Raden Panji Asmarabangun atau Pujonggo Anom dari kerajaan Kediri yang hendak melamar Dewi Sekartaji dari kerajaan Jenggala. Penyajian pertunjukan Barongan diawali dari iring-iringan prajurit berkuda pengawal Raden Panji dan Singo Barong. Ada beberapa peran tokoh lain dalam cerita Panji, yakni Bujangganong atau Pujonggo Anom, Joko Lodro atau Gendruwo, Pasukan berkuda, reog Nayantaka, dan Untub (Gainah). Pertunjukan Barongan dilengkapi beberapa instrumen musik yang berfungsi sebagai pengiringnya, yakni instrumen Kendang, Gedhuk, Bonang, Saron, Demung dan Kempul. Namun dalam perkembangannya ada beberapa penambahan instrumen modern, seperti Drum, Terompet, Kendang besar dan Keyboards. Adakalanya dalam beberapa peristiwa pertunjukannya dipadukan dengan kesenian Campursari.

Perkembangan Barongan di kabupaten Blora sangat pesat di tengah kehidupan masyarakat modern. Ada pergeseran atau penambahan fungsi, yaitu semula kesenian Barongan berfungsi untuk kepentingan ritual, seperti tradisi sedekah bumi, tradisi bersih desa, dan tradisi lamporan (tolak balak), kemudian berkembang melayani kepentingan hiburan. Dalam tradisi ritual lamporan mengharuskan keterlibatan Barongan karena tokoh Singo Barong dianggap sebagai pengusir balak. Sebaliknya fungsi hiburan, Barongan Blora telah menorehkan beberapa prestasi saat mengikuti parade maupun festival budaya baik di tingkat provinsi sampai tingkat internasional. Penampilan Barongan Blora dalam Parade Seni Budaya di Semarang tahun 2010 lalu berhasil meraih Juara 1 dari 35 perwakilan Kabupaten/Kota se Jawa Tengah. Pada tahun 2011 Barongan Blora sebagai wakil kesenian Provinsi Jawa Tengah dalam Parade Seni Budaya di Taman Mini Indonesia Indah. Pada tahun yang sama Barongan Blora tampil dalam event Jogjakarta International Ethnic Culture Festival 2011 di Monumen Serangan Umum 1 Maret Yogyakarta dan meraih Juara 2, mengalahkan beberapa kesenian dari daerah lain termasuk kesenian dari luar negeri. Oleh karena itu, fenomena ritual dan hiburan dalam kesenian Barongan Blora menjadi menarik untuk dikaji, dipahami, dan direfleksikan bagi kelangsungan agar tetap hidup dan bisa survive di tengah perubahan zaman beserta tuntutan yang menyertainya (lihat Rusiani, 2006 dan Slamet, 2014). 
Sungguhpun demikian, penelitian ini tidak terlepas dari penelitian sebelumnya yakni Penelitian Sudiana tentang "Desakralisasi Tari Barong dalam Kehidupan Sosial Budaya Masyarakat Bali” (Akademika, vol4, no,1, 2006). Penelitian ini menginformasikan bahwa bentuk pertunjukan Seni Barong di Bali mulai menghilangkan nilai kesakralan (ritual) karena perkembangan pariwisata. Penelitian Rusiani (2006) berjudul "Struktur dan Fungsi Pertunjukan Kesenian Barongan Dalam Upacara Ritual Pada Bulan Sura Di Dusun Gluntungan Desa Banjarsari Kecamatan Kradenan Kabupaten Grobogan". Penelitian ini menginformasikan bahwa Barongan dalam upacara ritual di dusun Gluntungan memiliki struktur dan fungsi yang berbeda dengan pertunjukan dalam acara hiburan dan acara ritual pernikahan. Namun prosesi pertunjukan Barongan dalam upacara ritual terdiri dari tiga bagian, yaitu (1) bagian pembuka berupa acara selamatan, (2) bagian inti sajian terdiri dari dua sub-bagian yaitu ritual kutuk (dupani) dan pertunjukan Barongan, dan (3) bagian penutup (arakarakan Barongan mengelilingi dusun). Penelitian Septiya tentang "Perkembangan Bentuk Topeng Barongan dalam Ritual Murwakala di kabupaten Blora (Catharsis, vol.4 no.2, 2015; Slamet, 2014) menjelaskan tentang perkembangan bentuk topeng Barongan dipengaruhi situasi zaman, terutama berkaitan dengan kekuasaan. Penelitian Murni yang berjudul "Seni Barongan di Kabupaten Tegal: ekspresi Simbolik Budaya Masyarakat Pesisiran" (Catharsis, vol.5 no.2, 2016). Penelitian ini menginformasikan bahwa seni Barongan merupakan salah satu bentuk ekspresi budaya pesisiran di Tegal, sedangkan bentuk topeng dan kostumnya dipengaruhi unsur-unsur keislaman. Dari hasil kajian pustaka pertunjukan Barongan di Jawa Tengah dibedakan menjadi dua gaya, yakni gaya pedalaman dan gaya pesisiran.

Atas dasar fenomena itulah penulisan ini difokuskan masalah dialektika ritual dan hiburan dalam kesenian Barongan Blora.

\section{METODE}

\section{Pendekatan dan Fokus Penelitian}

Penelitian ini merupakan jenis penelitian deskriptif kualitatif, dengan tujuan untuk menggambarkan serta menjelaskan kesenian Barongan di Blora sebagaimana adanya. Fokus dan atau sasaran penelitian adalah pertunjukan Barongan yang ditampilkan oleh grup-grup kesenian Barongan di Blora yang penyajiannya difungsikan untuk memenuhi kepentingan ritual dan hiburan masyarakat. 
Penelitian ini menggunakan pendekatan Performance studies dengan sub pendekatan Etnokoreologi yang mencakup pandang kontekstual dan tekstual dengan memanfaatkan teknik penafsiran (Narawati, 2003). Analisisnya memanfaatkan teori struktural-fungsional dan teori tindakan sosial menjadi latar kepentingan pertunjukan ritual dan hiburan.

Performance studies atau kajian penampilan adalah sebuah disiplin baru, sebuah pendekatan interdisipliner yang mempertemukan berbagai disiplin, antara lain kajian sejarah, linguistik, kritik sastra, antropologi, antropologi tari, etnomusikologi, folklore, semiotika, teater, dan koreografi. Dua tokoh terkemuka dari disiplin performance studies adalah antropolog Victor Turner (1990) dan Richard Schechner (2002) seorang aktor, sutradara teater, pakar pertunjukan, dan editor “The Drama Review”. Performance studies menekankan pentingnya untuk mempelajari pengalaman atau penampilan sebagai suatu proses - bagaimana penampilan mewujud di dalam ruang, waktu, konteks sosial, dan budaya masyarakat pendukungnya. Sebuah proses pertunjukan bila ditinjau dari urutan waktu dan ruang penampilan terdiri dari sebelum pertunjukan, pada saat pertunjukan, dan sesudah pertunjukan.

Penampilan (performance) memiliki tiga unsur pokok, yaitu: (1) penampilan adalah peristiwa, yang secara ketat atau longgar, bersifat terancang (misalnya: tempatnya, waktunya, pesertanya, aturannya) yang membedakan penampilan dari peristiwa-peristiwa lain yang terjadi secara kebetulan; (2) sebagai sebuah interaksi sosial, penampilan ditandai dengan kehadiran secara fisik para pelaku peristiwa dalam sebuah ruang fisik tertentu, dan (3) peristiwa penampilan terarah pada penampilan keterampilan dan kemampuan olah diri, jasmani dan rohani, atau keduanya. Lebih tegasnya, peristiwa penampilan selain melibatkan "performer" atau pemain juga melibatkan "audience" atau penonton (Lono, 2000:7-8).

Etnokoreologi merupakan disiplin antarbidang ilmu (multidisiplin) sangat relevan untuk mengkaji seni (pertunjukan) tari. Seni pertunjukan adalah sebuah rumpun seni yang berfungsi sebagai sarana ritual, hiburan pribadi, dan presentasi estetis yang mengajarkan bagaimana selayaknya manusia berperilaku sosial (Soedarsono dan Heddy dalam Pramutomo, 2007). 
Fungsi seni pertunjukan sebagai sarana Ritual memiliki ciri-ciri khas yaitu: (1) diperlukan tempat pertunjukan yang terpilih, kadangkala dianggap sakral; (2) diperlukan pemilihan hari serta saat yang terpilih, biasanya juga dianggap sakral; (3) diperlukan pemain yang terpilih, biasanya mereka yang dianggap suci atau yang telah membersihkan diri secara spiritual; (4) diperlukan seperangkat sesaji yang kadangkadang sangat banyak jenis dan macamnya; (5) tujuan lebih dipentingkan daripada penampilan secara estetis; (6) diperlukan busana yang khas (Soedarsono 1998: 60). Ritual seperti itu sering diekspresikan dalam bentuk upacara, seperti upacara menolak balak, upacara perubahan atau siklus dalam kehidupan manusia dari kelahiran, pernikahan dan kematian (Agus, 2007: 95). Sebuah ritual juga tidak terlepas dari suatu masyarakat beragama atau memiliki kepercayaan yang meyakininya. Sebuah ritual upacara yang sering dilakukan umat beragama adalah ritual untuk mendoakan para leluhur yang sudah meninggal, seperti upacara shraddha (agama Hindu), patangpuluh dan nyewu (kepercayaan Jawa), dan sebagainya. Dalam pelaksanaan ritual sering terikat oleh ketentuan (aturan atau persyaratan) yang berlaku dalam suatu masyarakat atau kebudayaannya, seperti ketentuan tempat, waktu, sarana prasarana, peralatan atau media tertentu.

Fungsi seni pertunjukan sebagai hiburan pribadi melibatkan diri sebagai penikmat dalam pertunjukan (art by participation). Bentuk pertunjukan yang berfungsi sebagai hiburan pribadi disajikan oleh penari wanita sebagai penghibur dan pihak yang berperan sebagai penikmat adalah kaum pria. Dalam jenis tari yang berfungsi sebagai hiburan pribadi tak ada aturan yang ketat di atas pentas, asal penikmat bisa mengikuti irama lagu yang mengiringi tari serta merespon penari wanita pasangannya kenikmatan pribadi akan tercipta (Soedarsono 1998: 60-98). Hiburan didefinisikan oleh Schrum (2004) dalam bukunya The Psychology of entertainment: concepts \& application sebagai suatu aktivitas yang dirancang untuk memberi kesenangan dan relaksasi kepada orang lain, dimana audience bersifat pasif (one way communication). Dengan demikian, segala sesuatu yang bersifat menyenangkan dan membuat rileks secara subyektif dapat dikategorikan sebagai hiburan.

Fungsi seni pertunjukan sebagai presentasi estetis merupakan seni kolektif, penampilannya menuntut biaya yang tidak sedikit. Untuk menampilkan sebuah 
pertunjukan tari diperlukan, penari, busana tari, penata rias, pemusik, panggung pertunjukan, penata panggung dengan perlengkapannya, dan sebagainya. Oleh karena penikmat sebagai penyandang dana produksi (production cost) menuntut sajian pertunjukan yang baik, sehingga sebagai penyajian estetis seni pertunjukan memerlukan penggarapan yang serius. (Soedarsono 1998: 108).

Berdasarkan uraian tentang hiburan dan ritual di atas, nampaknya kesenian Barongan ini bisa berada pada keduanya, ritual dan hiburan/tontonan. Jika demikian maka dapat dikatakan bahwa ada persandingan antara ritual dan hiburan sebagai fenomena dialektika. Sebagaimana diketahui bahwa metode dialektik Hegel terdiri dari tiga tahap, yaitu pertama adalah tesis yakni membangun suatu pernyataan tertentu, kedua adalah antitesis yakni suatu pernyataan argumentatif yang menolak tesis, dan yang ketiga adalah sintesis, yakni upaya untuk mendamaikan tegangan antara tesis dan antitesis. Biasanya para ahli mengaitkan konsep dialektika ini dengan filsafat Hegel, walaupun Hegel sendiri tidak pernah secara eksplisit menyatakan argumennya melalui konsep tesis, antitesis, dan sintesis. Sebaliknya Hegel justru menyatakan, bahwa ia mendapatkan argumen itu dari filsafat Kant. Lepas dari itu metode dialektik memang akhirnya menjadi sangat populer di tangan Hegel filsuf Idealisme Jerman.

Untuk memahami posisi Barongan antara ritual dan hiburan digunakan teori fungsional-struktural. Menurut teori fungsionalisme-struktual bahwa masyarakat merupakan sistem sosial yang terdiri atas bagian-bagian yang saling berkaitan dan saling menyatu dalam keseimbangan. Robert K. Merton merupakan tokoh fungsionalisme-struktural yang mengembangkan middle range theory dengan berdasarkan data empirik. Teori yang dikembangkan ialah bentuk penyesuaian yang meliputi konformitas (untuk mcncapai tujuan yang disepakat masyarakat digunakan cara yang disepakati masyarakat); inovasi (untuk mcncapai tujuan yang disepakati masyarakat digunakan cara yang baru); ritualisme (terlalu mementingkan cara sehingga tujuan terlupakan); retreatisme (menolak cara dan tujuan yang telah disepakati masyarakat), dan rebellion (menolak cara dan tujuan yang lama, kemudian mengajukan cara dan tujuan yang baru). Selain itu Merton juga memperkenalkan teori manifest (yang tampak/kelihatan) dan laten (tersembunyi/ belum nampak) dalam setiap kegiatan masyarakat. Jadi teori ini lebih menekankan keteraturan dan 
mengabaikan konflik maupun perubahan dalam masyarakat (Jazuli, 2011). Apabila kata 'masyarakat' diturunkan atau digantikan 'seni Barongan', maka seni dapat dipandang sebagai penyeimbang keberpihakan terhadap aktivitas instrumental, seperti pekerjaan rutin setiap hari dan fenomena dalam kesenian Barongan. Seni merupakan interes ekspresif yang mereduksi ketegangan yang diciptakan oleh peranan instrumental. Seni mampu mereduksi konflik sosial dan mengalihkan dari sumber agresi tertentu dengan menciptakan rasa aman dari dorongan bermusuhan.

Untuk mengkaji tindakan para pelaku dalam kesenian Barongan digunakan teori tindakan sosial Max Weber. Asumsi teoretisnya bahwa (1) tindakan manusia muncul dari kesadarannya sendiri maupun dari situasi eksternal dalam posisinya sebagai objek disebut 'kesadaran subjektif', (2) manusia sebagai subjek dalam bertindak selalu memiliki tujuan, (3) dalam bertindak manusia menggunakan cara, alat, prosedur, metode, dan perangkat yang dipandang dapat digunakan untuk mencapai tujuan, (4) keberlangsungan tindakan manusia hanya dibatasi oleh suatu situasi dan kondisi yang tidak bisa diubah dengan sendirinya, (5) manusia senantiasa memilah, memilih, dan menilai tindakan yang akan, sedang, dan yang telah dilakukan, (6) aturan-aturan atau prinsip moral diharapkan muncul pada saat pengambilan keputusan, (7) kajian tentang antar hubungan sosial memerlukan teknik yang bersifat subjektif, seperti verstehen, imajinasi, rekonstruksi simpati atau seakanakan mengalami sendiri (vicarious experience) (Jazuli, 2011).

\section{Lokasi Penelitian}

Lokasi penelitian adalah Blora, tepatnya di desa Berbak, desa Sambongrejo Kecamatan Ngawen, desa Todanan, dan desa Kunden kecamatan Kota Blora Kabupaten Blora, Provinsi Jawa Tengah. Lokasi penelitian (desa) tersebut dipilih karena banyak terdapat grup/kelompok Barongan yang masih eksis dan terkenal hingga saat ini, dan senantiasa mengadakan inovasi untuk menarik masyarakat penonton (hiburan). Misalnya grup Barongan Sekar Joyo, grup Barongan Seloganti, dan yang paling populer grup Barongan Risang Guntur Seto. Desa Berbak dan Sambongrejo kecamatan Ngawen dipilih sebagai lokasi penelitian karena masih sering mengadakan Barongan untuk sedekah bumi atau tolak balak (ritual). Dengan demikian peneliti lebih mudah mengamati dialektika kepentingan ritual dan hiburan dalam pertunjukan Barongan di Blora.

\section{Prosedur penelitian}


Prosedur penelitian meliputi beberapa tahapan sebagai berikut: (1) pengumpulan data melalui observasi langsung, wawancara mendalam dan studi dokumen.Langkahlangkah observasi dalam penelitian ini adalah 1) menggunakan alat dan bahan seperti buku catatan, kamera, alat tulis dan video perekam, 2) pengamatan pertunjukan Barongan dengan yang difokuskan pada bentuk, fungsi, karakteristik penyajiannya dan respons masyarakat penontonnya.

Dalam penelitian ini wawancara dilakukan dengan informan utama, yakni (1) Nurcahyo (pakar Barongan dari Berbak), (2) Adi Wibowo ketua grup Barongan Risang Guntur Seto, (3) Dina koreografer grup Barongan (3) beberapa pelaku kesenian Barongan Blora, di antaranya adalah Anto Singo Joyo dan Rusman (Pegawai Kelurahan). Dari Ari Wibowo dan Nurcahyo diperoleh informasi tentang asal usul Barongan di Blora, pembinaan organisasi dan fungsi Barongan bagi masyarakat sekitarnya. Dari Dina dan Nurcahyo diperoleh informasi mengenai model penggarapan, fungsi yang terkait dengan kepentingan Barongan dipertunjukkan, teknik penyajian, pelatihan hingga penampilan kesenian Barongan. Dari pelaku Barongan, Anto Singo Joyo diperoleh informasi tentang teknik permainan topeng Barongan. Dari Rusman sebagai aparatur pemerintah mendapat informasi mengenai posisi dan fungsi kelurahan (pemerintah) dalam partisipasi maupun pengembangan Barongan.

Dari hasil pengumpulan data dilakukan indentifikasi dan pengorganisasian data kemudian diskusikan dalam focus group discustion (FGD) trianggulasi untuk menetapkan keabsahan data. Akhirnya dilakukan analisis data mencakup bentuk, fungsi, nilai/makna dan karakteristik antara ritual dan hiburan.

Berikut ini disampaikan kerangka berpikir untuk menjawab masalah penelitian.

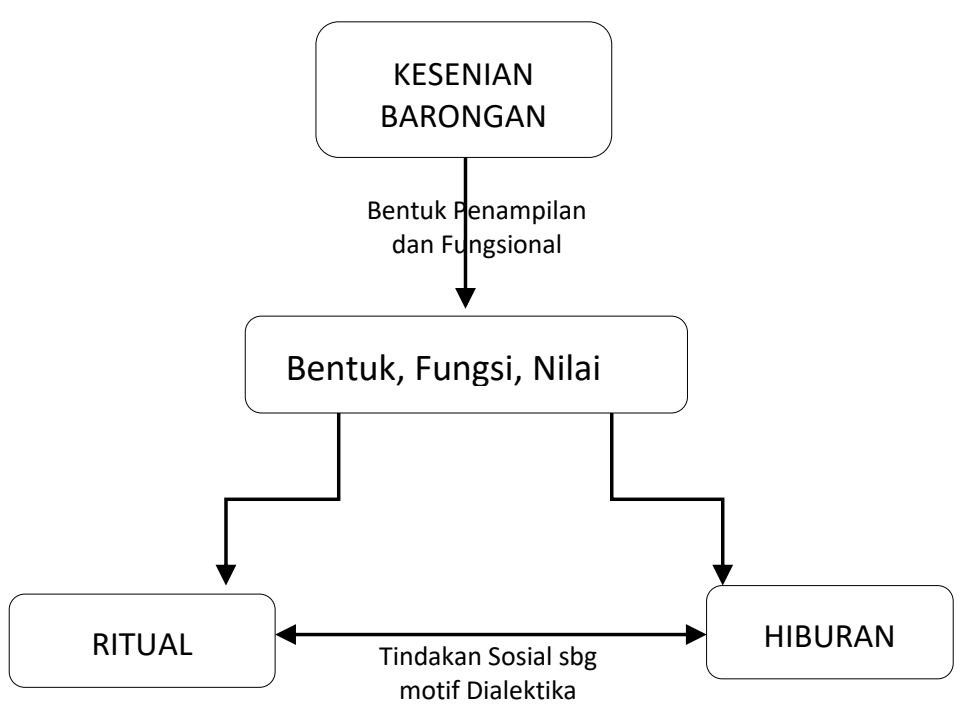




\section{HASIL PENELITIA DAN PEMBAHASAN}

\section{Bentuk Kesenian Barongan}

Kesenian Barongan Blora sebagai bentuk (model) seni pertunjukan ditampilkan dalam dua bentuk, yaitu dalam bentuk arak-arakan dan dramatari.

Bentuk pertunjukan arak-arakan atau pawai seringkali dapat ditemui pada acara ritual, seperti lamporan, ruwatan, sedekah bumi, hajat khitanan maupun karnaval budaya. Masyarakat Blora menggunakan Barongan sebagai sarana untuk mengusir wabah atau penyakit dengan mengarak Barongan keliling desa (terutama untuk khitanan). Oleh karena itu sebelum arak-arakan dilaksanakan diawali dengan talu kemudian slametan (doa bersama) sesuai dengan kepentingannya. Jika arak-rakan Barongan untuk khitanan, maka isi doanya selaras dengan khitanan. Demikian pula jika untuk kepentingan lamporan, ruwatan, dan sedekah bumi, isi doa berkitan dengan kepentingan yang menyertainya. Pertunjukan Barongan pada arak-arakan tidak mementingkan segi estetisnya melainkan pada tujuan pokok untuk tolak balak. Tujuan Arak-arakan Barongan adalah untuk memperoleh keselamatan yang didasari kepercayaan dan kekuatan magi yang dimiliki oleh Barongan. Masyarakat memiliki kepercayaan bahwa Barongan merupakan perwujudan binatang mitologi harimau yang dianggap memiliki kekuatan magi untuk melindungi dari marabahaya. Misalnya Barongan arak-arakan pada acara ritual sedekah bumi, peran kesenian Barongan sebagai pengiring atau pengawal sesaji, yakni mengawal pembawa sesaji yang berpindah dari satu tempat ke tempat lain yang dinamakan punden (tempat yang dianggap keramat). Punden bisa berupa sebuah tempat peninggalan seorang tokoh (petilasan cikal bakal), sumur atau sendang, dan makam. Jadi Barongan berfungsi untuk mengawal pembawa sesaji dari punden yang satu ke punden yang lain.

Barongan arak-arakan melibatkan seluruh tokoh pendukung cerita Barongan, yaitu mulai pembawa baliho bertuliskan nama grup dan daerah/desa, pasukan berkuda atau Jaranan, Panakawan, Barongan, Jaka Lodra, Bujangganong serta Barongan 
raksasa. Barongan dalam arak-arakan memiliki elemen-elemen penampilan yaitu cerita, gerak tari, iringan, rias dan busana, serta tempat penampilan/penyajian.

Bentuk pertunjukan Barongan dramatari terbagi dalam tiga bagian, yaitu sebelum pertunjukan, pada saat pertunjukan, dan akhir pertunjukan. Pada bagian sebelum pertunjukan terdiri atas sub-bagian, yakni slametan dan doa bersama, kemudian talu, dan diakhiri dengan padupan sebagai penutup bagian sebelum pertunjukan. Bagian pertunjukan terbagi beberapa adegan, yaitu adegan kiprahan Barongan, tari Bujangganong, jaranan, Barongan tunggal, Panakawan, adegan perang Joko Lodro, dan Barongan kerah sebagai adegan penutup pertunjukan.

Barongan dramatari juga melibatkan seluruh tokoh pendukung cerita Barongan dan elemen-elemen penampilan sebagaimana bentuk arak-arakan tetapi orientasinya lebih kepada kepentingan hiburan atau tontonan.

\section{Dialektika Ritual dan Hiburan}

Berdasarkan paparan tentang kedua bentuk pertunjukan yakni arak-arakan dan dramatari, menunjukkan adanya saling mempengaruhi, baik dalam penggarapan perlengkapan (tata rupa) sajian pertunjukan, fungsinya untuk melayani kepentingan, maupun dalam upaya menarik animo penonton. Pertunjukan Barongan arak-arakan selalu memiliki tema. Tema yang disajikan pada Barongan arak-arakan menyesuaikan tujuan hajatan atau ritualnya, seperti khitanan, perkawinan, ruwatan, dan lamporan. Sebab, tema dalam pertunjukan merupakan makna inti yang diekspresikan lewat problematika figur atau tokoh yang didukung oleh peran yang kompeten dalam sebuah pertunjukan. Prinsip dasarnya tema senatiasa berorientasi pada nilai-nilai kehidupan yang spiritnya memiliki sifat keteladanan, kepahlawanan, kesetiaan, kesatuan, kebersamaan, kegotong-royongan, keharmonisan, dan kebahagiaan. Bentuk pertunjukan Barongan arak-arakan yang semula melayani kepentingan ritual telah dikembangkan dan dikemas sebagai seni tontonan yang mampu menghibur, meskipun di dalamnya masih berisi perlengkapan bernuansa ritus, seperti ada tahapan dalam prosesinya yakni ada talu, berdoa bersama, padupan, dan tentu ada seperangkat sesaji. Cara pengembangan pertunjukan Barongan arak-arakan di antaranya adalah dengan menampilkan berbagai variasi bentuk topeng Barongan, mengembangkan gerakan kreatif yang berkesan antraktif, dan sebagainya. Cara pengembangan seperti ini 
dilakukan dengan tujuan agar pertunjukan Barongan untuk ritual tidak berkesan monoton seperti sebelumnya, yakni hanya sekedar arak-arakan tanpa atraksi maupun tanpa kreasi yang memukau. Selain itu juga pengembangan dalam hal rias dan busana, aransemen musik (gendhing baru) pengiringnya. Cara pengemasan seperti itu tentu menambah daya tarik penampilan Barongan sehingga bisa memberikan hiburan bagi peserta ritual mapun penonton prosesi ritualnya.

Sebaliknya, bentuk pertunjukan dramatari meskipun pertunjukan Barongan senantiasa menampilkan kebaruan yang menghibur merupakan wujud kreatifitas estetis untuk menarik animo penonton, meskipun dalam penampilannya juga masih menampakkan tradisi ritual. Hal ini dapat dicermati dari adegan-adegan yang atraktif, kreatif dan spektakuler tetapi tidak meninggalkan beberapa aspek ritual, seperti masih ada talu, berdoa bersama, dan padupan.

Dengan demikian, antara Barongan untuk melayani kepentingan ritual dan kepentingan hiburan, keduanya saling mempengaruhi, saling bersanding dan bersaing (dialektika), untuk menunjukkan eksistensinya. Masing-masing juga memiliki segmen penonton, penggemarnya. Sesungguhnya fenomena dialektika dalam seni pertunjukan Barongan tidak hanya terjadi pada konteks kepentingan yang berbeda yakni ritual dan hiburan, melainkan juga terjadi pada pertunjukan ritual maupun hiburan. Artinya pada Barongan untuk kepentingan ritual juga telah terjadi persaingan dalam merebut penanggapnya. Maka tak pelak bila ada pertunjukan Barongan untuk ritual dengan fasilitas dan prosesi yang lengkap dan ada yang relative sederhana saja yang penting tidak meninggal prinsip utama prosesi ritual. Demikian pula pada seni pertunjukan Barongan untuk kepntingan hiburan. Para grup Barongan bersaing dalam hal inovasi dan kreasi pada perlengkapan dan atraksi penampilannya. Muara dari semua tindakan tersebut adalah agar tetap diminati penonton, laku di pasaran sehingga banyak tanggapan. Dengan sering pentas Barongan tentu dapat menambah pemasukan pundipundinya, koceknya. Sebab tidak jarang satu grup Barongan bisa pentas 15-20 kali dalam setiap bulannya.

\section{SIMPULAN}

Kesenian Barongan adalah refleksi kreatifitas seni dan budaya masyarakat Blora yang memiliki sifat kerakyatan, seperti spontan, kesederhanaan, kekeluargaan, kasar, 
keras, dan berani karena benar. Hasil analisis menunjukkan bahwa posisi kesenian Barongan berada pada keduanya, yakni ritual dan hiburan/tontonan. Artinya ada persandingan sekaligus juga persaingan antara ritual dan hiburan sebagai fenomena dialektika. Persandingan tampak bahwa keduanya bisa hidup dan berkembang secara perdampingan, sedangkan persaingan tampak pada cara saling berebut pendukung (peserta, penonton). Tesisnya adalah ritual dan hiburan masing-masing hidup dalam kepentingannya. Antitesisnya adalah persaingan dalam menarik pendukungnya dan sama-sama mempertahankan nilai kerakyatan dalam kesenian Barongan. Sintesisnya bahwa keduanya bisa hidup berdampingan.

Rekomendasi yang diajukan adalah ditemukan adanya fenomena yang berhubungan dengan peningkatan ekonomi masyarakat melalui kegiatan kesenian Barongan. Ada relasi positif dengan kegiatan industri kreatif yang pada gilirannya dapat meningkatkan taraf ekonomi masyarakat Blora. Dengan mengaitkan industri kreatif pada kesenian Barongan dapat memberikan sumbangsih pemasukan masyarakat. Caranya adlah penampilan kesenian Barongan harus memanfaatkan hasil teknologi agar "laku jual"yang pada gilirannya mampu memberikan nilai tambah kepada kesenia Barongan sebagai seni tontonan-hiburan yang komersial.

\section{DAFTAR PUSTAKA}

Agus, Bustanuddin. 2007. Agama Dalam Kehidupan Manusia. Jakarta: Raja Grafindo Persada.

Departemen Pendidikan dan Kebudayaan. 1998. Deskripsi Kesenian Barongan. Blora: Proyek Pembinaan Kesenian Jawa Tengah.

Dewi, Anggraeni Purnama. 2016. "Komodiifikasi Tari Barong di Pulau Bali Berdasarakan Karakter Pariwisata”. Dalam Jurnal Panggung Vol. 26, No.3.

Heddy, Shri Ahimsa Putra. 2000. Ketika Orang Jawa Nyeni. Yogyakarta: Galang Press.

Jazuli, M. 2008. Pendidikan Seni Budaya: Suplemen Pembelajaran Seni Tari. Semarang: UNNES Press.. . 2011. Sosiologi Seni. Surakarta: UNS Press.

Lono Lastoro Simatupang, GR. "Budaya sebagai Strategis dan Strategis Budaya," GLOBAL -LOKAL. Jurnal Seni Pertunjukan Indonesia, Th.X, Juli 2000, 7-11. 
Narawati, Tati, 2003. "Performance Studies: An Introduction (Sebuah Tinjauan Buku)" dalam Panggung Jurnal Seni STSI Bandung, Nomor XXVII tahun 2003: 6-12.

Pambudi, Fifin Bagus Septiya. 2015. "Perkembangan Bentuk Topeng Barongan dalam Ritual Murwakala di kabupaten Blora”. Jurnal Catharsis: Journal of Arts Education, Vol.4, No.2.

Pramutomo, RM. 2007. Etnokoreologi Nusantara: Batasan Kajian, Sistematika, dan Aplikasi Keilmuannya. Surakarta: ISI Press.

Rusiani, Rina Veri. 2006. Struktur dan Fungsi Pertunjukan Kesenian Barongan Dalam Upacara Ritual Pada Bulan Sura Di Dusun Gluntungan Desa Banjarsari Kecamatan Kradenan Kabupaten Grobogan. Skripsi Unnes.

Schechner, Richard. 1990. Performance Theory. London: Routledge. . 2002. Performance Studies: An Introduction. London: Routledge

Richard Schechner, Performance Studies An introduction (New York: Routledge, 2002).

Slamet, MD. 2014. Barongan Blora: Menari di atas Politik dan Terpaan Zaman. Surakarta: Citra Sains LPKBN.

Soedarsono R.M. 1998. Seni Pertunjukan Indonesia di Era Globalisasi. Jakarta: Direktorat Jenderal Pendidikan Tinggi Departemen Pendidikan dan Kebudayaan

Soedarsono. 2002. Seni Pertunjukan Indonesia di era Globalisasi. Yogyakarta: Gadjah Mada University Press, 2002.

Sudiana, I Gusti Ngurah. 2006. "Desakralisasi Tari Barong dalam Kehidupan Sosial Budaya Masyarakat Bali”. Jurnal Akademika Vol. 4, No.1.

Turner, Victor. 1990. Masyarakat Bebas Struktur, Liminitas dan Komunitas. Terjemahan Y.W. Wartajaya Winangun. Yogyakarta: Kanisius, 1990. 